\title{
Fostering Language Skills Development through Fairy Tales: A Literature Study
}

\author{
Iva Riyadhus Sholichah \\ Applied Linguistics \\ Yogyakarta State University \\ Indonesia \\ riyadhus11@gmail.com
}

\author{
Widyastuti Purbani \\ Applied Linguistics \\ Yogyakarta State University \\ purbani@uny.ac.id
}

\begin{abstract}
In EFL, developing language skills is not merely concern on linguistics elements only. Some recent studies revealed that in good developing language skills needs to integrate another field such as literature. In this study, the researcher involved fairy tales as a medium in fostering language skills development. This fostering language skills is emphasized for early ages pupils. Fairy tales is used because it is considered suitable for all ages, besides, it also provides rich sources of language development, furthermore it has authentic model of language use. This study aims at proposing the use of fairy tales in developing language skills e.g.: listening, speaking, reading and writing. Later on, this study is going to discuss some problems: why is language crucial to early age children's development and how the way fairy tales fostering language skills development. In conducting this study, the researcher used library research method since its data is acquired from any library resources such as books, journals, articles, and any other resources which is relevant with. This study is expected to help language instructor to foster students' language skills development through literature, especially fairy tales.
\end{abstract}

Keywords_language skills; literature; fairy tales; authentic models

\section{INTRODUCTION}

Language is a pivotal part of life which always follows the running of life. The life of people is closely related to the language even before they were born to the world. The fundamental function of language is as a means of communication. Through language, people are able to share ideas, feelings, thoughts, and any other way of communication, whether in spoken, writen, or sign language. Cook [1] called language as the most unique thing about human beings. This shows that human is created as special creature rather than other creatures, because humans use language to speak to each other. In addition, Octavio Paz, as cited in IB Middle Years Programme [2] revealed that language is what makes us human. It is a resource against the meaningless noise and silence of nature and history. This obviously shows that language is a vital part of life which cannot be separated from life itself. Developing language skills is far better conducted when people are still in early ages [3]-[6]. However, it is not easy to teach language skills to early age children, therefore, the language instructors (parents or teachers), moreover for EFL should be able to create an interesting learning. Regarding this research, the researcher is going to propose an exciting learning for fostering language skills development by using literature, especially fairy tales.

In this case, literature and language is inseparable. Language is the part of literature itself. Literature is meaningless without language in it. Boris Pasternak as cited in IB Middle Years Programme [2] stated that literature is the art of discovering something extraordinary about ordinary people and saying with ordinary words something extraordinary. No matter how literature appears extraordinary, the aesthetic aspect emerge in a literature is built by language. Therefore, language and literature are completing each other to create a valuable work. In this research, literature is used as a media for fostering language skills such as listening, speaking, reading and writing. Subsequently, these language skills developments are able to help people to communicate globally in an era which demand for it.

Currently, as the development of era, it demands people to acquire another language besides their mother tongue because, it is believed that knowing one language is not enough [7]. Therefore, learning second language is considered as a need for the sake of fulfilling the demands of this era. Subsequently this need will be linked to the effort of fostering language skills development. In this research, the researcher is going to discuss the way fostering language skills development through fairy tales. In conducting this research, the researcher was inspired by some previous study: 1) The Concept of L2 User and the Goals of Second Language Learning written by Willy Juanggo. This research concern on the concept of second language acquisition in purpose of communication. 2) Fostering Children's Literacy and Language Development through Play: A Look the Role of Early Childhood Educators in Preschool and Kindergarten Classrooms, written by Kelly D. Russell. This research concern on the way fostering children's literacy through Play.

\section{THEORETICAL FRAMEWORK}

\section{A. EFL Teaching through Literature}

In terms of EFL, to develop language skills people tend to solely concern on linguistics elements. However, some recent studies revealed that in fostering language skills development 
is able to conduct by integrating another element such as literature. Literature is deliberately integrated in developing language skills because of its rich language material which potentially provide authentic model of language use. In nineteenth ESL or EFL teaching was predominated by the use of Grammar Translation Method (GTM) in which literary text was used as the object of translation in GTM. Then, in 1960 GTM was replaced by structuralism approach, where literature was no longer used, because structuralism was concerned with appropriateness of structure (grammatical aspect) without content or interpretation of the written word. Period after period, language teaching method was developing and getting better. Unfortunately, its development made literature being ignored instead [8]. Nevertheless, in 1980 literature began to find its way back to EFL teaching. In this case, EFL teaching purposes to enhance communicative competence and providing a means of critical thinking training, and aesthetic appreciation [9] and also encourage students to be aware of culture and the society of the relevant country in a literary text used in EFL teaching.

The use of literature in language teaching is theoretically advantageous since it offers four benefits i.e.: authentic material, cultural enrichment, language advancement, and personal growth [10]. Nevertheless, this reseacrh would only focus on its advantageous on language advanceent which in this research is referred to language skills development. Carter and McRae [11] recommended the use of literature in helping students go beyond acquiring basic knowledge of the language, to learn about the language and how it works. This recommendation is based on the consideration that literature, especially fairy tales can help to develop the four language skills (i.e. reading, writing, listening, speaking). Besides, literature also provided the knowledge of language areas (i.e. vocabulary, grammar, and pronunciation) [12].

According to Hismanoglu [13] the use of literature as a technique of teaching, especially in purpose of developing two basic languages: language skills (i.e. reading, writing, listening, and speaking); and language areas (i.e. vocabulary, grammar and pronunciation) is popular in terms of foreign language learning and teaching currently. Also, Collie and Slater [10] support the idea of using literature as the media in teaching language. This consideration is based on some reasons: valuable authentic material, cultural enrichment, language enrichment, and personal involvement. However, this research will only focus on language enrichment as well as the focus of this research.

On the other hand, Maley [14] made a list of why literature become the potential resource in teaching language: universality; non-triviality; personal relevance; variety; interest; economy and suggestive power; and ambiguity.

\section{B. Fairy Tales}

Fairy tale is a story which involves folkloric features such as fairies, goblins, princes, and princesses [15]. According to Kready [16] tales were told orally, not in written form because fairy tale was the part of an oral tradition [16]-[17]. Originally, the term fairy tale came from France. In 1697, Madame
d'Aulony started publishing volumes of fantasy stories under the collective title Les Contes des fees (Tales of Fairies) [18].

Choosing appropriate text is a need to teach English in EFL or ESL Classroom [19]. Regarding to this, fairy tales is considered effective to use in Fostering language skills because its rich sources of language development besides, it also suitable to use for all levels (beginner to advance) and all ages (young learners to adults) [8]. Choudary [20] proposed that in developing students' English Language Skill, teaching literature also exposes them to the practical use of language. In this case, fairy tales is considered able to be likely supplementary teaching materials for English language learners. Fairy tales is a valuable resource of language development. Therefore, teacher may use fairy tales as the media of language learning. This idea is supported by Lazar [21] who revealed that literature provided wonderful source material for eliciting strong emotional responses from students and using it in classroom is a fruitful way of involving the learner as whole person.

Children literature which refers to fairy tale is used in developing skill by the reason that it is the suitable source in all ages. Simple-vivid concrete language-young reads understand more of what readers do than what they say or think. While, young adult readers can follow more complex language structures [22]. Based on those statement, Chen [23] concluded that children literature is ideal for English Language Learners. Language and literature is a unity which cannot be separated in terms of developing language skills. This idea supported by Matthew [24] who stated that it is unlikely separating language or literacy learning from literature. In terms of fostering language skills development on early ages children, fairy tale is suitable for them because its content is considered valuable and rich of language skills and language areas sources.

\section{DISCUSSION}

\section{A. Early Ages as suitable span for Fostering Language Skills Development}

It has been known that early ages are the suitable span for fostering language skills development. In supporting this idea, researchers agreed that language and literacy derive from the first days of a child's life [25]. In this case, literacy means an ability to interpret and understand messages relayed from others as means to communicate [26]. The environment which surrounds children give a big influence toward their language skills development. By listening and interacting with people around them, they become literate member in society. Hence, a good environment results a positive influence toward children's language skills development. On the contrary, Mielonen \& Paterson [25] emphasized that a poor social skill result from limited social interaction which (in theory) interfere with language development.

Regarding to this case, Maria Montessori, Jean Piaget, Lev Vygotsky, and Brian Cambourne suggest that when children interact with the world around them, they are likely to remember first-hand experiences rather than vicarious 
experiences that are told to them by others. All four theorists emphasized that children mostly learn by performance, not by prompt. All the theorists believed that childhood is the appropriate span to foster language skills development. Even childhood is considered as the best span to foster language skills development, nevertheless, language instructor should be able to create a joyful learning in order to they do not get bored in learning language, and it is expected to help the children to acquire language maximally. It is well established that a rich language experience during the first years of life are essential for successful first language (L1) development [2729].

\section{B. Fostering Language Skills Development through Fairy Tales}

Fairy tales is believed able to emerge good impression toward pupils in terms of learning language. In language lessons, there are four skills need to be developed, such as: reading, writing, speaking, and listening. Harmer [30] divided the four language skills into two types: receptive skills including reading and listening; and productive skills, including speaking and writing.

\section{1) Reading Skill}

Developing reading skill is needed. Most of language production skills grow out from such text that the students hear or see [30]. Through reading, students may get many knowledge and lesson. Also, reading is able to help students in language skills production. Subsequently, students will be able to create their own language production such as a writing. Writing skill development can grow very well through reading. By reading, students will get many inspiration to produce such the similar or innovative work as well as they read. Therefore, it is important to begin with pre-reading activity in order to set up a topic, to focus their attention in what they are going to read, activate students' background knowledge of the topic [30]-[32]. The purpose of this activity is to prepare for language skill production too [15]. In short, reading is the basic skill which is needed to be developed for preparing another language skills demands, especially language skills production. Fairy tales help children to notice language areas such as past tenses, adjectives, comparatives, etc. Those language areas can be acquired by the students through reading activity. In addition, fairy tales also providing much vocabularies which is used in a fairy tales. By the two inputs: acquiring the knowledge of language area and acquiring vocabularies, this will This will help the students in developing language skills production better.

Different from Harmer, Noaman [12] revealed that reading is receptive interactive skill. It is called receptive because in reading students acquire information from what they read, no matter how short or long the text, reading activity will always give information to the reader. While reading is called interactive because this activity involves and takes place inside the reader's mind.

\section{2) Listening Skill}

As well as reading skill, listening skill is categorized as receptive language skill. It is an input skill which will help students to develop their other language skills especially productive language skill. Through listening skill, students get knowledge input as well as students get when they are reading. Regarding with the research, the use of fairy tales in developing listening skill is considered helpful. Listening activity aims at getting information or getting entertainment. In terms of fairy tales, listening for it gives two advantages: getting information and getting entertainment, In which information and entertainment acquired from listening fairy tales may help the students to have new knowledge. In common, the advantage of fairy tales in developing language skill production is similar to the way reading skill. Likely, listening to the fairy tales will help students more in speaking skill, while reading the fairy tales will help the students more in writing skills. The advantage of listening to the fairy tales in terms of developing language skills especially in speaking is able to acquire by imitating the way of narrator's speaking. So that is why, students will be able to speak in good way by learning the way of narrator's speaking such as the intonation, the caesura, tempo, and any other speaking models.

Regarding to listening to literature, Neugebauer \& CurrieRubin [33] pointed out that listening to an accomplished reading of interesting texts offers benefits for second language acquisition as well as reading development. In this case, the benefit of listening to literature is not only gaining entertainment, but also Rasinski [34] stated that listening helps developing vocabulary and understanding literary devices. Listening repeatedly to the same story give advantage as well as Frost [35] said that in terms of listening, the listener will gain insight and understand themes more thoroughly following multiple reading of the same text.

\section{3) Writing Skill}

Current researcher has discussed the role of literature in developing language skill in order to achieve linguistic proficiency among EFL learners [36]. In this case, Lazar [21] revealed that by using literary text as a technique to teach EFL, learners will be able to function effectively in the acquisition of foreign language skills, because of its high educational potential, motivating and interpretative qualities. As well as the use of fairy tales in fostering language skills especially in writing skill, it is considering helpful in developing writing skill. Writing skill can also be developed through fairy tales. Inspired by the text, the instructor can set up some kind of creative writing tasks. Students are able to write a newer version of such famous fairy tales, for example a new version of Snow White Story, besides, students are also able to make summarize of fairy tales. In addition, Student may write their own fairy tales by making their own idea to their writing by taking some example from such famous fairy tales as the inspiration. Students is also able to write an alternative ending, answer the question what if... [32], [37]. Hence, fairy tales can be used as the media for fostering 
writing skill by taking example and imitating the way writing models used in the fairy tales to the students own writing.

Noaman [12] stated that literature especially fairy tales can be a powerful and motivating source for writing whether as a model or as subject matter. Fairy tales become model of writing when the students write in the similar way as the way the original text. In this case, students may imitate the content, theme, organization, or style of writing. On the other hand, fairy tales may be able to be a subject matter when the students use their own style of writing or their original thinking by using their own creativity. According to Rosenblatt [38] Writing has strong relation with reading. This strong relation comes from the similar process of reading and writing in the case of creating meaning audience analyzing and monitoring. The experience of reading can influence the way students writing. Hence, the better reading experience, the better it results to students' writing. Creative writing means an approach that emphasizes imaginative self-expression. It also means the ESL/EFL learners' capacity to respond vividly and spontaneously, and to convey responses freely in their writing [39]. A creativity in writing is resulted from great experiences in terms of reading or listening. Students get input of experiences through reading and listening activity, which subsequently influence the way children writing.

\section{4) Speaking Skill}

To foster speaking language skill is considered difficult for some instructor. In this case, fairy tales are able to help student in developing speaking skill. Student will participate enthusiastically if we give them suitable topic or task [30]. Fairy tales provides good themes and topics for discussion, therefore, it is able to help the student to develop speaking skill [40]. By the varying topics which is provided by the fairy tales, teacher can set up students' activities in many ways. Lepin [15] proposed a way of enacting fairy tales into role play. It involves students' speaking ability. Here, the teacher may prepare such questionnaire related to the topic. Students are working in pairs or in a small group to discuss the answer of questionnaire and sharing their ideas. Subsequently, students shar their answer to the class. In addition, Skopinskaya [32] proposed a further way by changing the written text of fairy tales into play. Here, the students directly involved their self into a play. Also, Wallin [41] proposed way of developing speaking skill by storytelling activity, because it demands the student to be active in speaking. Regarding this model, teacher can ask the students to retell the fairy tales they have read before. This kind of activity is helpful for students, because the students here will use their ability in changing a work from one form to another form of work. Besides, it prosecutes the student to be able to speak up, because a play will always need ability of speaking. Hence, this will train the students' speaking skill.

Noaman [12] stated that speaking is productive interactive language skill. It is productive when students produce language orally by the purpose to convey their ideas to other. While, it is interactive because the students involve directly in this skill by speaking up. This activity needs for knowledge of the language rules (the ability to construct sentences that are grammatically correct) as well as social rules for implementing this knowledge to produce speech.

\section{CONCLUSION}

Teaching English in EFL classroom is not merely referred its source to non-literary text only. Many researchers found literature is very helpful in terms of fostering language skills development. Through fairy tales, learners gain two aspects simultaneously: language development aspects (language skills and language areas); and entertainment aspect. Fairy tales become a potential resource in teaching language in EFL classroom. It gives many advantageous and valuable lesson for learners. Therefore, it is considerably effective and suitable to be used for teaching language. Hence, it is expected to be able to help language instructors to teach language in a fruitful way.

\section{ACKNOWLEDGMENT}

I would like to thank to thank to the Almighty God who always give help in all my importance. I also thank to my lecturers in Applied Linguistics department, Yogyakarta State University, Dr. Widyastuti Purbani, M.A., Prof. Dr. Pratomo Widodo, Prof. Dr. Burhan Nurgyantoro for support and guidance. Best regards for my parents, big family, and all friends who always pray and support me to finish this paper. May all be in shelter of God.

\section{REFERENCES}

[1] V. J. Cook, Second Language Teaching. London: Hodder Education, 2008.

[2] IB. Middle Years Programme, Language and Literature Guide. Switzerland: International Baccalaureate Organization, 2014.

[3] B. Buckley,B. 2003. The Children’s Communication Skills- From Birth to Five Years. London: Routledge Falmer.

[4] J. Riley, Language and Literacy 3-7. London: PCP, 2006.

[5] R. Sage, Supporting Language and Communication: A Guide for School Support Staff. London: PCP, 2006.

[6] K. D. Russel, “Fostering Children's Literacy and Language Development through Play: A Look at the Role of Early Childhood Educators in Preschool and Kindergarten Classrooms,” Thesis, Psychol. and Chil. Develop., Dept. Coll. of Lib. Arts., California Polytech. State Univ., San Luis Obispo, 2012.

[7] W. Juanggo, "The Concept of L2 User and the Goals of Second Language Learning,” Jurn. Stud. Komun., vol. 1, no. 2, pp. 101-115, 2017.

[8] P. Pardede, "Using Short Stories to Teach Language Skills,” J. of Engl. Teach., vol. 1, no. 1, pp. 14-27.

[9] M. L. Bretz, "Reaction: Literature and Communicative Competence: A Springboard for the Development of Critical Thinking and Aesthetic Appreciation,” Forei. Lang. Annals, vol. 23, no. 4, pp. 335-338, 1990.

[10] J. Collie and S. Slater, Literature in Language Classroom, 5th ed. Glasgow: Cambridge University Press, 1991.

[11] R. Carter and J. McRae, "Reading Language: A Fifth Skill,” IATEFL Issues, vol. 165, no. 10, 2001.

[12] N. N. Noaman, "Literature and Language Skill," Al-Ustath, vol. 2, no. 204, pp. 123-134, 2013

[13] M. Hismanoglu, “Teaching English through Literature,” J. of Lang. and Ling. Stud., vol. 1, no. 1, pp. 53-66, 2005. 
[14] A. Maley, A. 1989. "Down from the Pedestal: Literature as Resource in Literature and the Learner: Methodological Approaches,” Cambridge: Modern English Publication, 1989.

[15] M. Lepin, "Fairy Tales in Teaching English Language Skills and Values in School Stage II,” Thesis, Univ. of Tartu, 2012.

[16] L. F. Kready, A Study of Fairy Tales. Boston: Houghton Mifflin, 1916.

[17] R. Karven, English Fairy Tales and Legends. National Trust, 2009.

[18] D. L. Ashliman, Folk and Fairy Tales. USA: Greenwood Press, 2004.

[19] A. Keshavarzi, "Use of Literature in Teaching English,” Procedia: Soc. and Behav. Sci., vol. 46, pp. 554-559, 2012.

[20] S. Choudary, “A Literary Approach to Teaching English Language in a Multicultural Classroom,” High. Learn. Res. Commun., vol. 6, no. 4, 2016.

[21] G. Lazar, Literature and Language Teaching, a Guide for Language Teaches and Trainers. Cambridge: Cambridge University Press, 1993.

[22] C. Temple, M. Martinez, and J. Yokata, Children’s Book in Children’s Hands: An Introduction to their Literature. San Fransisco: Pearson Allyn and Bacon, 2004.

[23] M. Chen, “Teaching English as a Foreign Language through Literature,” Theor. and Prac. in Lang. Stud., vol. 4, no. 2, pp. 232-236, 2014.

[24] L. Matthews, "The Role of Literature in Language and Literacy Learning,” Aus. Lit. Educat. Assoc. Audi., vol. 16, no. 3, 2011.

[25] A. M. Mielonen and W. Paterson, "Developing Literacy through Play," J. of Inq. \& Act. in Edu., vol. 3, no. 1, pp. 15-46, 2009.

[26] Y. L. Tsao, “Using Guided Play to Enhance Children’s Conversation, Creativity and Competence in Literacy,” Education, vol. 128, no. 3, pp. 515-520, 2008.

[27] N. Chomsky, Syntactic Structure. The Hague, Netherlands: Mouton, 1957.

[28] S. B. Heath, Ways with Words: Language, Life, and Work in Communities and Classrooms. New York: Cambridge University Press, 2004.

[29] G. Wells, The Meaning Makers. Pourtsmouth, NH: Heinemann, 1986.

[30] J. Harmer, The Practise of English Language Teaching, 4th ed. Pearson Education Limited, 2007.
[31] S. Reid, Book Bridges for ESL Student: Using Young Adult Children's Literature to Teach ESL. USA: Scarerow Press, 2002.

[32] L. Skopinskaya, A Handbook of English Language Teaching. Tallinnn: Koolibri Publisher, 1996.

[33] S. R. Neugebauer and R. Currie-Rubin, "Reading Alouds in Calca, Peru: A Bilingual Indigenous Context,” Read. Teach., vol. 62, pp. 396-405, 2009.

[34] T. V. Rasinsky, "The Effects of Repeated Reading and Repeated Listeningwhile Reading on Reading Fluency,” Research Report, Kent State Univ., 1989. ERIC database. (ED304666).

[35] S. B. Frost, "Increasing Reading Achievement through Repeated Paired Reading Practicum Paper,” Nova University, 1990. ERIC database (ED323508).

[36] H. Elhabiri, "Teaching the Writing Skills through Literary Text," Dissertation, Djilali Liabes Univ., 2013.

[37] M. B. Bagg, Folk Literature in the Foreign Language Classroom, 1991. [Online]. Available: http://eric.ed.gov/ERICWebPortal/contentdelivery/servlet/ERICServlet? accno=ED343432. [Accessed Jun. 17, 2018].

[38] Rosenblatt, Writing and Reading: The Transactional Theory (Technical Rep, No. 13). California: National Center of Writing, 1988.

[39] M. Ghani and D. Muhammad, "The Effect of Teaching English through Literature on Creative Writing at HSSC Level in Pakistan,” Int. J. of Engl. Lingui., vol. 7, no. 2, pp. 142-150, 2017.

[40] J. Wallin, "Storytelling and Language Development," Thesis, Malmo Hogskola Univ., 2015. [41] T. L. Hanlon, General Guidelines for Teaching with Folk Tales, Fairy Tales, Fables, Ballads, and Other Short Works of Folklore, 1999. [Online]. Available: http://www.ferrum.edu/applit/studyg/studygfolk.htm. [Accessed Jun. 10, 2012].

[41] J. Wallin, “Storytelling and Language Development,” Thesis, Malmo Hogskola Univ., 2015. 